\title{
Pemberdayaan Guru dalam Peningkatan Layanan Bimbingan Konseling di SD/MI Muhammadiyah Se-Surakata pada Era Komunikasi Global
}

\author{
Harun Joko Prayitno ${ }^{1}$, Murfiah Dewi Wulandari ${ }^{2}$, Choiriyah Widyasari ${ }^{3}$, Nursalam ${ }^{4}$, Krisma Anugra \\ Malaya $^{5}$, Faisal Yusuf Bachtiar ${ }^{6}$, Hengki Hermawan ${ }^{7}$, Desi Tri Wulandari ${ }^{8}$, Madya Giri Aditama ${ }^{9}$ \\ ${ }^{1,2,3,4,5,6,7,8}$ Fakultas Keguruan dan Ilmu Pendidikan, Universitas Muhammadiyah Surakarta, Indonesia \\ ${ }^{9}$ Fakultas Keguruan dan Ilmu Pendidikan, STKIP Muhammdiyah Batang, Indonesia
}

\section{INFORMASI ARTIKEL}

\section{Histori Artikel:}

Submit: 13 Agustus 2020

Revisi: 30 Agustus 2020

Diterima: 1 September 2020

Publikasi: 3 September 2020

Periode Terbit: Desember 2020

\section{Kata Kunci:}

layanan bimbingan konseling, komunikasi global,

berkehidupan bermasyarakat,

kelompok diskusi terpumpun

Correspondent Author:

Harun Joko Prayitno

Fakultas Keguruan dan Ilmu Pendidikan

Universitas Muhammadiyah Surakarta,

Indonesia

Email: harun.prayitno@ums.ac.id

\begin{abstract}
ABSTRAK
Tata kelola penyelenggaraan pendidikan dan pembelajaran jenjang sekolah dasar dihadapkan banyak tantangan dan persoalan pada era komunikasi dan komputasi global ini. Layanan kegiatan bimbingan dan konseling dari guru kepada siswa dan orang tua/wali memerlukan adaptasi cepat supaya pendidikan dan pembelajaran mampu mengikuti perkembangan dan tunturan perubahan tersebut. Tujuan kegiatan pengabdian masyarakat ini adalah untuk memberdayakan dan meningkatkan layanan bimbingan konseling bagi guru-guru SD/MI Muhammadiyah Se-Surakarta pada era komunikasi dan komputasi global. Kegiatan ini dilaksanakan dengan pendekatan holistik reflektif partisipatif (HRP). Kegiatan dirancang bersama dengan melibatkan kepala sekolah dan guru unggulan sebagai model layanan bimbingan. Kegiatan diteruskan dengan totorial KDT (Kelompok Disukusi Terpumpun), dan partisipasi aktif serta diakhiri dengan refleksi secara holistik. Hasil kegiatan pengabdian ini adalah bahwa guru-guru SD/MI kemampuan layanan bimbingan dan konselingnya diperlukan pengayaan dan pemutakhiran secara berkala dan terus-menerus. Layanan bimbingan dan konseling guru-guru SD/MI perlu menyeimbangkan antara kompetensi profesional dan kompetensi sosial. Kompetensi sosial ini memerlukan jangka waktu dan proses yang lebih lama karena berhubungan dengan hakikat kemampuan dan kemandirian anak dalam berkehidupan bermasyarakat. Layanan bimbingan konseling dari guru kepada anak-anak dan orang tua/wali pada era komunikasi dan komputasi global memerlukan adaptasi teknik dan strategi yang kontekstual.
\end{abstract}

\section{Pendahuluan}

Tata kelola pendidikan dan pengembangan pendidikan dihadapkan banyak persoalan dan tantangan untuk menuju SDM unggul dan Indonesia maju. Permasalahan yang dihadapi oleh sekolah (pendidikan), khususnya pada tingkat dasar, hingga sekarang ini bahwa semua guru jenjang Sekolah Dasar/Madrasah Ibtidaiyah (SD/MI) perlu memiliki kompetensi bimbingan dan konseling. Sehingga layanan bimbingan dan konseling di sekolah dasar tersebut belum dilaksanakan secara maksimal. Demikian pula pada SD/MI Muhammadiyah di se-Solo Raya yang terdiri dari Surakarta, Sragen, Wonogiri, Klaten, Karanganyar, dan Boyolali belum ada guru khusus (konselor) yang melaksanakan layanan kegiatan bimbingan dan konseling. Oleh sebab itu, guru-guru SD/MI tersebut perlu dibekali kemampuan dalam melaksanakan layanan kegiatan bimbingan dan konseling.

Selain permasalahan di atas, rendahnya mutu layanan BK di sekolah yang disebabkan rasio yang tidak sesuai antara guru BK dan jumlah siswa yang seharusnya 
e-ISSN 2716-0327

doi: 10.23917/bkkndik.v2i2.11853

1:150, guru BK yang belum sepenuhnya menguasai kompetensi sebagai konselor, dan guru BK yang masih merangkap tugas yang lain di sekolah (Kamaluddin, 2011). Penelitian Ulfa, Farozin, \& Triyanto (2015) menyebutkan minat siswa untuk konseling pada guru BK separo lebih (57\%) tidak melakukan konseling dengan guru BK nya mereka memilih menceritakan masalahnya dengan temannya. Hal ini menandakan bahwa peran guru BK masih kurang dipercaya oleh siswa. Selain itu penilaian siswa terhadap guru BK separo lebih $(62,13 \%)$ belum menjadi guru BK yang ideal. Persepsi guru BK yang ideal menurut siswa di sini adalah guru BK yang ramah dan tidak galak, mengerti perasaan siswa, bisa dipercaya dan sebagai panutan dalam berperilaku.

Keberadaan Peraturan Menteri Pendidikan dan Kebudayaan Republik Indonesia Nomor 111 Tahun 2014 tentang Bimbingan dan Konseling pada Pendidikan Dasar dan Pendidikan Menengah, maka setiap tingkat pendidikan dasar dan menengah perlu melaksanakan kegiatan layanan bimbingan dan konseling secara profesional. Istilah Bimbingan dan Konseling tidak bisa dipisahkan dalam dunia sekolah, meskipun sampai sekarang masih belum banyak sekolah yang mendirikan Bimbingan dan Konseling sebagai suatu lembaga khusus untuk memberikan layanan bagi siswanya khususnya di Sekolah Dasar. Jika dilihat sekarang ini banyak sekali permasalahan yang muncul di sekolah yang memerlukan penanganan khusus, seperti kasus pelecehan seksual, bulyying (perundungan), narkoba, dan permasalahan siswa lainnya yang berhubungan dengan akademik (Wulandari \& Marsudi, 2018).

Bimbingan dan konseling adalah upaya sistematis, obyektif, logis, dan berkelanjutan serta terprogram yang dilakukan oleh konselor atau guru bimbingan dan konseling untuk memfasilitasi perkembangan peserta didik/konseli untuk mencapai kemandirian dalam kehidupannya (Tohirin, 2007). Bimbingan dan konseling memiliki tujuan membantu peserta didik dapat mencapai tujuan perkembangannya yang meliputi aspek pribadi-sosial belajar (akademik) dan karir (Yusuf \& Nurihsan, 2005). Prinsip-prinsip bimbingan dan konseling pada umumnya berkenaan dengan sasaran pelayanan, masalah klien, tujuan dan proses penanganan masalah, program pelayanan dan penyelenggaraan pelayanan (Prayitno, 2004).

Proses konseling merupakan hubungan yang berlangsung antar dua pribadi, yaitu konselor dan siswa (klien). Dua pribadi ini saling bertemu dan bertatap muka sehingga terjadi interaksi yang melibatkan faktor-faktor kognitif maupun afektif. Seorang ingin memberikan sesuatu dan pihak yang lain menginginkan sesuatu. Konselor sebagai pribadi dengan macam-macam latar belakang kepribadiannya akan mempengaruhi keberhasilan konseling. Terdapat tiga hal yang mempengaruhi profesionalitas seorang konselor, yaitu: kualitas pribadi konselor, pengetahuan tentang profesi konselor, dan penguasaan keterampilan dalam konseling (Wulandari \& Marsudi, 2018).

Keteladanan seorang konselor sangat dipersyaratkan dalam dunia bimbingan dan konseling. Hadirnya pribadi konselor yang bisa diteladani klien merupakan salah satu aspek pokok keberhasilan proses konseling. Motivasi klien untuk tersentuh perasaannya, karena usur keteladanan kepribadian konselor. Keteladanan ini akan teridentifikasikan dalam bentuk kepribadian, wawasan, dan keterampilan, serta amal kebajikan konselor terhadap klian. Konselor bersikap jujur, saleh, dan berpandangan luas, serta penuh perhatian terhadap klien (Willis, 2004).

Pada kurikulum 2013 disebutkan, mengharuskan peserta didik menentukan peminatan akademik, vokasi fisik dan pilihan lintas peminatan serta pendalaman peminatan yang memerlukan layanan bimbingan dan konseling. Dengan demikian Permendikbud Nomor 111 tahun 2014 dan kurikulum 2013 menghendaki dilaksanakannya kegiatan layanan bimbingan dan konseling di sekolah, termasuk sekolah dasar. Oleh sebab itu secara formal diperlukan guru khusus (konselor) yang melaksanakan layanan bimbingan dan konseling tersebut. Dalam kenyataan, kegiatan layanan bimbingan dan konseling pada tingkat pendidikan dasar secara formal belum ada.

Oleh sebeb itu, tujuan utama dilaksanakannya kegiatan pengabdian masyarakat ini adalah untuk memberdayakan guru-guru SD/MI Muhammadiyah khususnya agar mampu memberikan layanan bimbingan dan konseling secara maksimal dan profesional di sekolah sejalan dengan era komunikasi dan komputasi global sekarang ini.

\section{Metode Pelaksanaan}

Kegiatan pengabdian ini melibatkan guru-guru dari sekolah dasar atau Madrasah mitra Muhammadiyah seSolo Raya. Metode utama dilaksanakan melalui metode pelatihan. Peserta pengabdian masyarakat ini masing sekolah terdiri dari tiga guru SD/MI Se Surakarta. Kegiatan 
pengabdian ini diikuti 221 peserta dari berbagai jenjang kelas bawah maupun kelas atas.

Materi pelatihan meliputi materi tentang langkahlangkah mengidentifikasi dan menangani permasalahan peserta didik serta penguasaan modifikasi perilaku pada anak. Metode pelaksanaan yang ditempuh dalam kegiatan pengabdian masyarakat ini mencakup beberapa tahap sebagai berikut.

Tahap pertama, tahap persiapan, yaitu persiapan merupakan tahap awal sebelum pelaksanaan pengabdian. Pada tahap ini ada beberapa hal yang dilakukan: (a) koordinasi internal, dilakukan oleh tim untuk merencanakan pelaksanaan secara konseptual dan operasional; (b) koordinasi secara eksternal, dilakukan dengan pihak luar yang terkai; (c) pembuatan instrumen pengabdian, seperti: presensi, PPT, dan sebagainya; dan (d) persiapan undangan, tempat lokasi, dokumentasi, dan persiapan lainnya.

Tahap kedua adalah pelaksanaan kegiatan. Tahap ini merupakan tahap sosialisasi dilaksanakan yang mencakup hal-hal sebagai berikut: (a) FGD; (b). pelatihan dengan role play; dan (c) pendampingan keberlanjutan program.

Tahap ketiga merupakan tahap tindak danjut dan pengembangan kegiatan, meliputi: (a) evaluasi dan refleksi program; (b) pengembangan program bimbingan berkelanjutan, dan (c) tindak lanjut berupa pendampingan dan layanan secara terpadu dan terintegrasi.

\section{Hasil Pelaksanaan dan Pembahasan}

Bimbingan adalah bantuan yang diberikan kepada individu dalammembuat pilihan-pilihan dan penyesuaian-penyesuaian yang bijaksana. Sedangkan pengertian konseling yaitu suatu rangkaian pertemuan langsung dengan individu yang ditujukan pada pemberian bantuan kepadanya untuk dapat menyesuaikan dirinya secara lebih efektif dengan dirinya sendiridan dengan lingkungannya (Prayitno dan Erman Amti, 2004). Lingkungan merupakan salah satu aspek penting dalam pembentukan jati diri anak (Prasetya, I.,et al, 2019).

Bimbingan dan konseling merupakan suatu proses pemberian bantuan kepada individu secara berkelanjutan dan sistematis yang dilakukan oleh seseorang yang telah mendapat latihan khusus dengan tujuan agar individu dapat memahami dirinya, lingkungannya, dan dapat mengarahkan diri serta menyesuaikan diri dengan lingkungan untuk mengembangkan potensi dirinya secara optimal untuk kesejahteraan dirinya dan kesejahteraan masyarakat (Anas Salahudin, 2010). Bimbingan lebih pada tindakan preventif dan konseling pada kuratif atau menangani anak yang memiliki masalah.

Bimbingan dan konseling adalah upaya sistematis, obyektif, logis, dan berkelanjutan serta terprogram yang dilakukan oleh konselor atau guru bimbingan dan konseling untuk memfasilitasi perkembangan peserta didik/konseli untuk mencapai kemandirian dalam kehidupannya (Tohirin, 2007). Bimbingan dan konseling memiliki tujuan membantu peserta didik dapat mencapai tujuan perkembangannya yang meliputi aspek pribadi-sosial belajar (akademik) dan karir (Yusuf \& Nurihsan, 2005). Prinsip-prinsip bimbingan dan konseling pada umumnya berkenaan dengan sasaran pelayanan, masalah klien, tujuan dan proses penanganan masalah, program pelayanan dan penyelenggaraan pelayanan (Prayitno, 2004).

\section{a. Gambaran Umum Pelaksanaan Kegiatan}

Pengabdian diawali dengan pemaparan materi tentang perkembangan peserta didik SD dan modifikasi perilaku. Setelah pemaparan diadakan FGD dengan mengelompokkan perkabupaten. Ada 6 kabupaten yaitu Sragen, Sukoharjo, Klaten, Boyolali, Wonogiri, Karanganyar dan satu kotamadya Surakarta. Pada awal FGD fasilitator menanyakan apakah peserta mengetahui Permendikbud No 111 tahun 2014 tentang Bimbingan dan Konseling pada Pendidikan Dasar dan Pendidikan Menengah, hampir seluruh peserta 99\% belum mengetahuinya. Ketidaktahuan ini mengisyaratkan kurangnya sosialisasi Permendikbud No 111 tahun 2014 pada tingkat pelaksana yaitu di sekolah-sekolah khususnya sekolah dasar.

FGD dengan mendiskusikan permasalahan-permasalahan peserta didik perkabupaten/kotamadya. Dari hasil FGD ditemukan permasalahan peserta didik hampir sama di semua kabupaten/kota yaitu kesulitan belajar dan masalah perilaku. Setelah identifikasi permasalahan dilanjutkan bagaimana mengatasi permasalahan dengan prosedur pemecahan masalah yang terdiri beberapa tahap yaitu: identifikasi masalah, diagnosis, prognosis, terapi, evaluasi dan follow up. Masing-masing SD perkabupaten mendiskusikan dan menyusun prosedur pemecahan masalah peserta didik, kemudian dipresentasikan di depan. Dari hasil presentasi dapat diketahui peserta sudah mampu melakukan pemecahan permasalahan peserta didik. Namun masih ada kendala bagi peserta jika dihadapkan pada terapi untuk permasalahan yang mereka 
tidak mampu untuk melakukan terapi. Hal ini dapat diatasi dengan mengalihtangankan kasus peserta didik pada ahlinya (psikolog, dokter, dll).

Pengenalan terapi pada peserta didik salah satunya melalui modifikasi perilaku. Setelah peserta mendapatkan materinya mereka melakukan FGD pada kasus-kasus yang telah didiskusikan di awal. Dari hasil FGD mengenai modifikasi perilaku pada peserta didik kemudian peserta mempresentasikan dengan role play bagaimana menerapkan terapi modifikasi perilaku pada anak di depan.

Pengabdian yang diikuti 200-an peserta guru dan kepala sekolah se-Solo Raya ini masih terdapat kendala pada keterampilan guru dalam menyelesaikan permasalahan peserta didik untuk kasus-kasus tertentu. Untuk itu PGSD FKIP Universitas Muhammadiyah Surakarta memberikan pendampingan kepada guru dalam menyelesaikan permasalahan peserta didik untuk datang di laboratorium BK yang ada di gedung C lantai 3. Hal ini dikarenakan belum semua SD memiliki lembaga BK di sekolahnya.

Pelaksanaan FGD kegiatan ini di Gedung Walidah lantai 7 Kampus Induk Universitas Muhammadiyah Surakarta. Kegiatan ini dihadiri oleh sejumlah Majelis Dikdasmen Se-Solo Raya, Kepala Sekolah, Guru-guru MI/SD Muhammadiyah Se Solo Raya seperti pada gambar 1 .

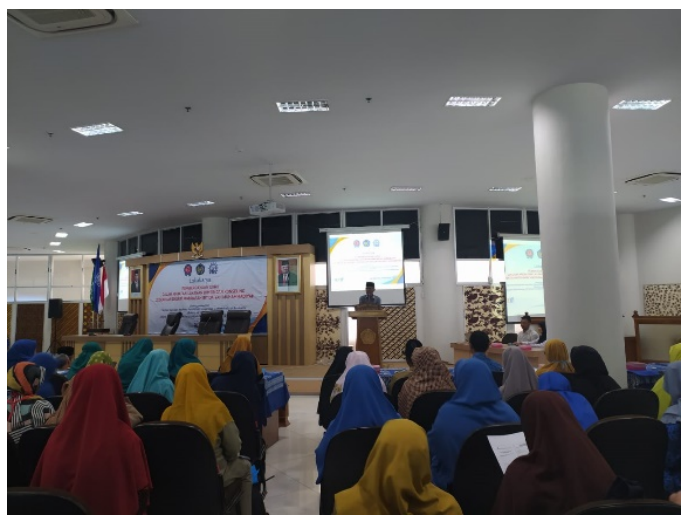

Gambar 1. Gambaran Umum Pelaksanaan FGD

\section{b. Pelaksaan Layanan Bimbingan dan Konseling}

Pelaksanaan layanan bimbingan dan konseling dalam kegiatan ini secara umum mangacu pada Asmani (2010) yang mendasarkan pada tujuh jenis layanan bimbingan dan konseling. Ketujuh jenis dan tahapan tersebut adalah: (a) pertama, layanan orientasi merupakan layanan bimbingan dan konseling yang memungkinkan klien memahami lingkungan (seperti sekolah) yang baru dimasukinnya. Hal ini untuk mempermudah dan memperlancar peserta didik agar dapat berperan di lingkungan yang baru; (b) kedua, layanan bimbingan dan konseling yang memungkinkan peserta didik (klien) menerima dan memahami berbagai informasi (seperti informasi pendidikan dan jabatan). Informasi ini nantinya dapat digunakan sebagai bahan pertimbangan dan pengambilan keputusan untuk kepentingan klien. Kedua tahap ini merupakan dasar-dasar pelekasanaan dalam layanan BK di sekolah.

Ketiga, (c) layanan bimbingan dan konseling yang menungkinkan klien memperoleh penempatan dan penyaluran yang tepat (misal penyaluran dan penempata di dalam kelas, kelompok belajar, jurusan/ program studi, kegiatan ekstrakulikuler); (d) keempat, layanan bimbingan dan konseling yang menungkinkan klien mengembangkan sikap dan kebasaan dalam belajar yang baik, maksudnya dalam hal menguasai materi pelajaran yang cocok denngan kecepatan dan kemampuan dirinya; 9 (e) layanan bimbingan dan konseling yang menungkinkan klien mendapatkan layanan langsung tatap muka secara perorangan dengan guru pembimbing. Hal ini dilakaukan dalam rangka pembahasan dan pengentasan permasalahan pribadi yang dideritanya. Ketiga tahap pelaksanaan ini merupakan inti dari pelaksanaan layanan BK di sekolah.

Selanjutnya, (f) fayanan bimbingan dan konseling yang menungkinkan klien secara bersama-sama melalui dinamika kelompok, memperoleh berbagai bahan dari narasumber tertentu (terutama dari guru pembimbing) membahas bersama-sama topic yang berguna menjunjung untuk pemehaman dan kehidupannya mereka sehari-hari dan peengembangan kemapuasn sosial baik sebagai 
individu maupun sebagai pelajar; dan (g) layanan bimbingan dan konseling yang menungkinkan klien memperoleh kesempatan untuk pembahasan dan pengentasan permasalahan yang dialaminya melalui dinamika kelompok. Masalah yang dibahas adalah masalah-masalah pribadi yang dialami oleh masing-masing anggota kelompok.

Ketujuh layanan bimbingan dan konseling diatas tidak seluruhnya diterapkan di sekolah dasar, akan tetapi

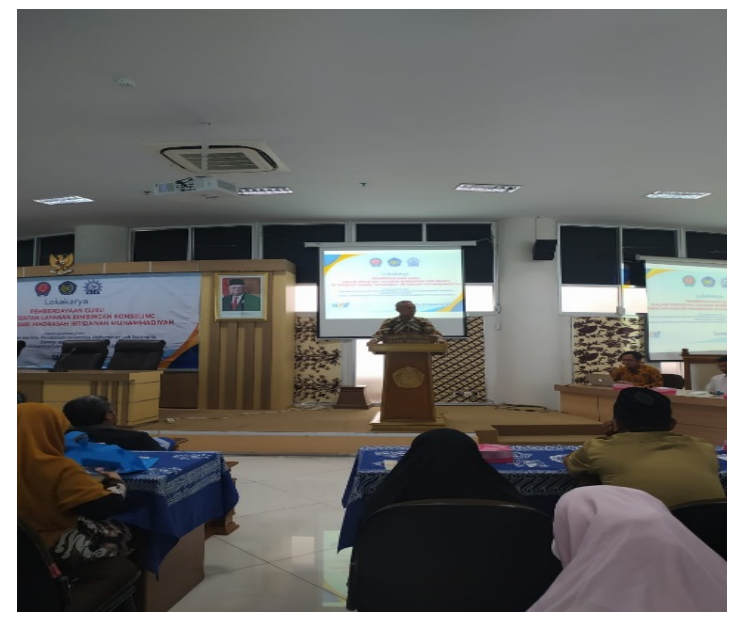

Gambar 2. Ilustrasi Tahapan dan Strategi Layanan BK

\section{c. Strategi Pemahaman terhadap Peserta Didik}

Pada dasarnya ada dua teknik memahami peserta didik, yaitu teknik tes dan non tes. Teknik mana yang tepat digunakan, sangat tergantung dengan jenis data apa yang akan dipahami oleh guru. Ada data yang tepat digali dengan tes, tetapi juga ada data atau informasi yang tepat digali atau dipahami melalui teknik non tes. Berikut ini secara singkat akan dikemukakan beberapa teknik memahami peserta didik (Wulandari \& Marsudi, 2018).

Strategi pemahaman pseserta didik dapat dilakukan dengan teknis tes dan nontes. Teknik tes dilaksanakan melalui beberapa data atau informasi tentang klien yang dapat dipahami dengan teknik tes ini. Misalnya, tes hasil belajar, yaitu tes yang digunakan untuk mengetahui keberhasilan belajar siswa (klien) setelah berakhirnya proses pembelajaran. Selanjutya, tes psikologis, seperti: tes IQ, tes bakat, tes minat, dan lain sebagainya. Khusunya tes psikologis, konselor dapat bekerja sama dengan psikolog untuk mengetahui aspek psikologis tentang kliennya, untuk kepentingan proses konseling.

Selanjutnya teknik non tes. Teknik ini sebagai salah satu alat tes maka teknik non tes ini juga ada beberapa

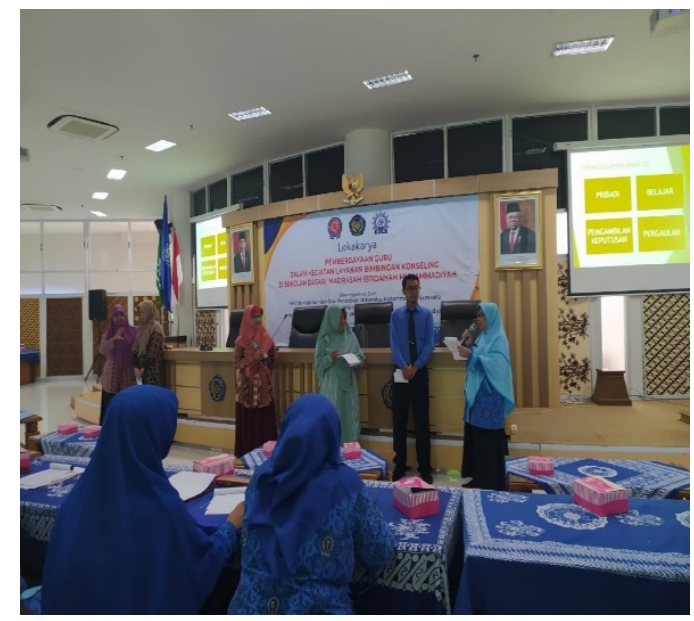

disesuaikan dengan permasalahan peserta didik, kebutuhan, kondisi sekolah dan program sekolah itu sendiri. Masing-masing layanan bimbingan dan konseling memiliki bentuk-bentuk kegiatan pendukung untuk membantu peserta didik mengatasi masalahnya.

Pelaksanaan layanan BK dengan berbagai tahapan dan strategi diilustrasikan melalui gambar 2 .

macam sesuai dengan data atau informasi apa yang dibutuhkan dari pihak klien. Adapun macam-macam teknik non tes ini antara lain sebagai berikut. Teknik angket, yaitu seperangkat pernyataan atau pertanyaan tertulis yang harus diisi oleh responden (klien) terkait dengan aspek atau informasi yang diperlukan yang berhubungan dengan permasalahan yang dihadapi. Melalui angket inilah diaharapkan konselor mengetahui lebih banyak informasi yang perlu dipahami untuk kepentingan proses konseling. Teknik wawancara, yaitu teknik memehami klien dengan segala informasi yang diperlukan melalui wawancara (interview) antara konselor dengan klien. Agar konselor lebih banyak memperoleh yan g terkait dengan permasalahan klien, maka konselor perlu menyusun pedoman wawancara (interview guide) terlbih dulu agar wawancara terfokus pada permasalahan klien.

Termasuk di dalamnya teknik dokumenasi, yaitu teknik memahami klien melalui dokumen yang sudah ada pada diri klien atau yang telah tersimpan di sekolah, misalnya: identitas klien, hasil belajar, identitas orang tua, data kesehatan, dan lain sebagainya. Teknik sosiometri, yaitu teknik memahami klien dalam hal aspek 
hubungan sosial klien dengan teman sekelas/sekolah. Hubungan sosial ini terkait dengan frekuensi dan intensitas hubungan sosial anak dengan teman-temannya. Melalui sosiometri ini konselor dapa mengetahui kedudukan sosial klien, apakah ia termasuk anak yang : star (anak yang populer) yang klien yang banyak teman yang menyenaginya, anak yang terisolir (tidak ada yang senang padanya), hubunganyang berisifat klik, dan lain sebagainya.

Salah satau teknik nontes yang paling pokok adalah teknik observasi. Yaitu teknik memahami klien dengan cara mengamati prilaku klien pada kondisi atau situasi tertentu, misalnya pada saat : proses pembelajaran, istirahat, olah raga, pramuka, sebelum jam masuk sekolah, dan lain sebagainya. Melalui observasi yang sistematis, konselor dapat memperoleh data atau informasi perilaku klien sehari-hari, sebagai dasar untuk keperluan konseling terhadap klien yang bersangkutan.

Strategi untuk mengukur pemahaman dan internalisasi layanan BK di sekolah dilustrasikan melalui gambar 3 .
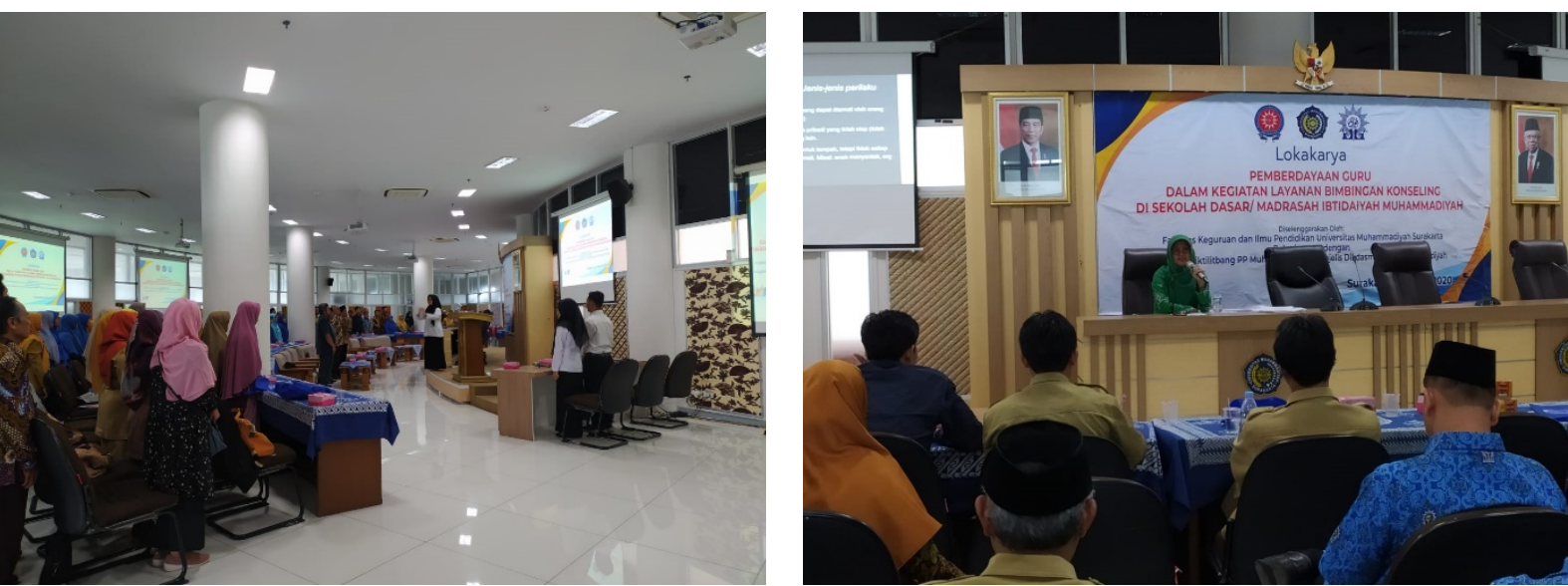

Gambar 3. Strategi untuk mengukur pemahaman dan internalisasi layanan BK di sekolah

\section{d. Upaya Penganganan Permasalahan Peserta Didik}

Seorang konselor perlu memahami permasalahan yang ada pada anak usia SD. Anak usia SD mempunyai beberapa tugas sesuai dengan proses perkembangan mereka. Apabila tugas-tugas perkembangan tidak terpenuhi secara proposional dapat menimbulkan permasalahan pada diri anak. Masalah yang sering muncul diantaranya menurut Roos L. Mooney (dalam Prayitno, 2004) adalah perkembangan jasmani dan kesehatan, keadaan lingkungan, kegiatan sosial, hubungan muda-mudi, keadaan pribadi, moral agama, keadaan rumah dan keluarga, masa depan pendidikan, penyesuaian terhadap tugas-tugas sekolah, kurikulum sekolah dan prosedur pengajaran. Pendidikan merupakan suatu proses pendewasaan dan pemandirian. Oleh sebab itu pendidikan yang utama adalah pendidikan karakter (Sabardila, et al, 2019).

Selain masalah di atas, masalah seiring dengan perkembangan teknologi, informasi, dan globalisasi. Perkembangan teknologi komunikasi seperti gadget dapat berdampak pada kesehatan, psikologis anak, prestasi belajar, sikap anti sosial, dan sebagainya (Ernawati, 2015;
Rozalia, 2017). Penggunaan gadget pada anak-anak semakin lama mengalami peningkatan, hal ini perlu diwaspadai oleh orang tua karena dampak yang ditimbulkan.

Hasil umum menunjukkan bahwa sejumlah masalah yang dihadapi anak terutama masalah yang muncul dalam proses belajar di sekolah, antara lain (Effendi, 2016): (a) persoalan pribadi; masalah yang mengganggu "aku" atau "ego". Sering pula masalah ini disebut masalah emosional; (b) masalah belajar; masalah yang berkaitan dengan masalah psikis dan kegiatan akademis bisa bersumber karena persepsi, motivasi, memori, kurang informasi, kebiasaan belajar yang salah, prestasi belajar di bawah kemampuanny; (d) masalah pengambilan keputusan; memahami dan mengenal pentingnya pengambilan keputusan dalam hidupnya; dan (e) problema pergaulan antar pelajar; pergaulan antara siswa satu dengan yang lain dapat menggunakan berbagai macam cara, media, dan lingkungan. Jenis masalah pergaulan antara lain: pergaulan bebas, ketergantungan obat, penyimpangan tingkah laku seksual, minum-minuman keras, kecanduan rokok, perkelahian antar siswa, pencurian, dan lain-lain. 


\section{Simpulan}

Pengabdian yang diikuti leih dari 215 peserta guru dan kepala sekolah se-Solo Raya diharapkan dapat menambah wawasan dan keterampilan peserta dalam melakukan layanan BK di sekolahnya masing-masing. Hal ini sebagai upaya untuk meningkatkan kualitas dalam pelayanan terhadap peserta didik yang dikarenakan pemerintah belum menerapkan Permendikbud No 111 tahun 2014 karena masih kurangnya tenaga guru BK untuk disalurkan di sekolah dasar. Penguatan guru-guru SD/MI dalam layanan BK perlu dilakukan secara berkala dan berkesinambungan. Model dan strategi layanan BK perlu diadaptasi sesuai dengan kondisi dan perubahan zaman.

\section{Daftar Pustaka}

Effendi, K. (2016). Proses dan Keterampilan Konseling. Yogyakarta: Pustaka Pelajar.

Ernawati, W. (2015). Pengaruh penggunaan gadget terhadap penurunan tajam penglihatan pada anak usia sekolah (6-12 tahun) di sd muhammadiyah 2 pontianak selatan, 5-6.

Kamaluddin. (2011). Bimbingan dan Konseling Sekolah, $447-454$.

Prasetya, I., Ulima, E. T., Jayanti, I. D., Pangestu, S. G., Anggraeni, R., \& Arfiah, S. (2019). Kegiatan
Bimbingan Belajar dalam Meningkatkan Minat Belajar Siswa di Kelurahan Bolong Karanganyar. Buletin KKN Pendidikan, 1(1).

Prayitno. (2004). Pedoman Khusus Bimbingan dan Konseling. Jakarta: Dirjen Pendidikan Dasar dan Menengah, departemen Pendidikan Nasional.

Rozalia, M. F. (2017). Hubungan Intensitas Pemanfaatan Gadget Dengan, 5(September), 722-731.

Sabardila, A., Budiargo, A. D., Wiratmoko, G., Himawan, J. A., Triutami, A., Intansari, A., ... \& Suistri, S. (2019). Pembentukan Karakter Peduli Lingkungan melalui Kegiatan Penghijauan pada Siswa MIM Derasan Sempu, Boyolali. Buletin KKN Pendidikan, 1(2).

Tohirin. (2007). Bimbingan dan dan Konseling di Sekolah dan Madrasah Berbasis Integrasi. Jakarta: Raja Grafindo Persada.

Ulfa, Z. M., Farozin, M., \& Triyanto, A. (2015). Hubungan Antara Persepsi terhadap Guru Bimbingan dan Konseling Ideal dengan Minat Konseling Siswa. Jurnal Penelitian Bimbingan Dan Konseling, 1(1), 21-31.

Willis, S. (2004). Konseling Individual (Teori dan Praktek). Bandung: ALFABETA.

Wulandari, M. dewi, \& Marsudi, S. (2018). Layanan Konseling $S D$ (1st ed.). Surakarta: Muhammadiyah Unit Press (MUP).

Yusuf, S., \& Nurihsan, J. (2005). Landasan Bimbingan dan Konseling. Bandung: PT Remaja Rodaskarta. 